\title{
Effect of Doum Fruit (Hyphaene Thebaica) Extract on Some Biochemical Parameters, Enzyme Activities and Histopathological Changes of Pancreas in Alloxan Induced Diabetic Rats
}

\author{
Naglaa Abd Fattah Abd el Halim Hassan \\ Department of Home Economics, Faculty of Agriculture, Alexandria University, Alexandria, Egypt \\ Email: kan2h20207@gmail.com
}

How to cite this paper: el Halim Hassan, N.A.F.A. (2020) Effect of Doum Fruit (Hyphaene Thebaica) Extract on Some Biochemical Parameters, Enzyme Activities and Histopathological Changes of Pancreas in Alloxan Induced Diabetic Rats. Food and Nutrition Sciences, 11, 207-219.

https://doi.org/10.4236/fns.2020.113016

Received: February 20, 2020

Accepted: March 16, 2020

Published: March 19, 2020

Copyright $\odot 2020$ by author(s) and Scientific Research Publishing Inc. This work is licensed under the Creative Commons Attribution-NonCommercial International License (CC BY-NC 4.0). http://creativecommons.org/licenses/by-nc/4.0/ (c) (i) (8) Open Access

\begin{abstract}
Medicinal plants have been used in the treatment of some diseases like diabetes. One of them is doum fruit extract. The study was conducted to evaluate effect of doum fruit extract on some biochemical parameters, including enzyme activities and histopathological changes of pancreas in alloxan induced diabetic rats. Animals were allocated into five groups of rats, two groups, several as control (one normal and one diabetic rats) and the other three groups were induced diabetic with doum extract $(0.5,1$ and $2 \mathrm{~g} / \mathrm{kg} \mathrm{b} \cdot \mathrm{wt})$ which were given every other day by stomach tube for 6 weeks. Evaluation was made for glucose, insulin, lipid profile, enzyme activities, antioxidant activity and histopathological changes of pancreas. The results showed that doum fruit extract decreased blood glucose, insulin, total cholesterol (TC), triglyceride (TG), total lipid (TL), low-density lipoprotein cholesterol (LDL-C), lactate dyhadreygenase (LDH), alanine and aspartate amino transferase (ALT, AST), alkaline phosphatase (ALP) and Malondialdehyde (MDA) while plasma catalase activity and high density lipoprotein cholesterol (HDL-C) were significantly $(p<0.05)$ increased. Therefore, the results of this study demonstrated that the active compounds present in the doum extract have a positive effect on the biochemical parameters of diabetic rats.
\end{abstract}

\section{Keywords}

Doum Fruit Extract, Alloxan, Histopathological, MDA, Biochemical Parameters 


\section{Introduction}

Since the beginning of history nature is a source of medicinal factors including herbal medicine. It is one of the most popular sources for primary health care of about $65 \%-80 \%$ of the world's population, especially in developing countries. This is due to better cultural acceptability, better compatibility with the human body in addition to fewer side effects [1] [2].

Medicinal plants are common plants used in Egypt for diabetes known as chronic disorder carbohydrate metabolism, characterized by hyperglycemia. This depends on the lack of insulin secretion resulting from reduced efficiency. Symptoms are worsen due to obesity and lack of physical activity by the sedentary lifestyle [3].

Diabetes is considered one of the most common diseases around the world as 285 million people suffer from diabetes, and this rate will rise to $54 \%$ by 2030 [4]. Thus the disease as yet remains a serious cause of morbidity and mortality. Diabetes can be defined as a disorder in glucose and insulin homeostasis, which is characterized by the inability of glucose control, involving impairment in insulin stimulation, secretion and action. This results in post prandial hyperglycemic rise, which if not properly controlled can put patients at increased risk of developing macrovascular and microvascular complications [5]. In Egyptian folk medicine there are some plants used diabetes treatment of such as Lupinus termis L., Fenugreek (Trigonella foenum-graecum), Allium species and doum (Hyphaene thebaica) [6].

Hyphaene thebaica is a desert palm native to Nile valley (Egypt, sub-Saharan Africa) and West India which is considered as one of the useful plants of the world. The trunk of this small palm is commonly branched into two branches like $\mathrm{Y}$ and often each branch is divided further into a $\mathrm{Y}$ form, giving the tree a very distinctive appearance; as it is dichotomous and arborescent in nature [7].

Doum is one of the commonly consumed beverages in traditional places in Egypt. It is rich in polyphenolic compounds. The drink is prepared by infusing the dried ground fruit pulp in hot water. And it is widely consumed as a health tonic as a remedy for hypertension [8]. It is comparatively rich in protein as well as in essential minerals which in most instances exceed the recommended daily allowance (RDA), and thus may keep their balance and ratios among those in need.

Several previous studies have indicated that doum is antimicrobial, antioxidant, and anti-diabetic, as well as it reduces blood lipids [9] [10] [11]. In addition doum extracts reduced blood glucose in diabetic rats [12].

Therefore, the present study aimed to study the effect of doum fruit ( $\mathrm{Hy}$ phaene thebaica) extract on some biochemical parameters, enzyme activities and histopathological changes of pancreas in alloxan induced diabetic rats.

\section{Materials and Methods}

\subsection{Materials}

Doum powder was obtained from the local market in Alexandria, Egypt Alloxan 
was obtained from Alpha Co. (Mumbai, India) and was dissolved in saline solution $(0.9 \% \mathrm{NaCl}, \mathrm{pH}$ 7). The dose of alloxan (120 mg/kgof BW per day) was chosen to induce diabetes in rats in Egypt according to [13] [14]. All chemicals and reagents used in this study were of analytical grade and sigma co.

\subsection{Preparation of the Doum Fruit Extract}

The fruit was cleaned, debris removed and then separated into pulp and seed. The pulp was dried and ground into fine powder. The doum fruit extract was made by boiling $10 \mathrm{~g}$ of the powdered pulp in $100 \mathrm{ml}$ of distilled water for $2 \mathrm{~min}$ [15]. Then filtered with Whatman filter paper no. 1 and stored at $4^{\circ} \mathrm{C}$.

\subsection{Experimental Design}

Thirty male albino rats (150 - $160 \mathrm{~g}$ weight) obtained from the department of home economics, faculty of agriculture, Alexandria University, Egypt. The design of the experiment was approved by the local committee in Alexandria University, Egypt, according to the protocol conforms to the guidelines of the National Institutes of Health (NIH). The animals were housed in cages under proper environmental conditions. Animals were housed 5 per cage and fed a commercial diet. Rats were fed pellets consisting of $30 \%$ berseem (Trifolium alexandrinum) hay, $25 \%$ yellow corn, $26.2 \%$ wheat bran, $14 \%$ soybean meal, $3 \%$ molasses, $1 \% \mathrm{CaCl}_{2}, 0.4 \% \mathrm{NaCl}$, a mixture of minerals (dicalcium phosphate, $45.8 \mathrm{mg}$; magnesium sulfate, $15 \mathrm{mg}$; manganese sulfate, $6.15 \mathrm{mg}$; ferric sulfate, 50 mg; potassium iodide, $0.392 \mathrm{mg}$; copper sulfate, $5 \mathrm{mg}$; cobalt sulfate, $0.1 \mathrm{mg}$; and zinc sulfate, $5 \mathrm{mg} / \mathrm{kg}$ pellets) and vitamins (6000 IU of vitamin A, $40 \mathrm{mg}$ of vitamin E, $6 \mathrm{mg}$ of vitamin C, $4 \mathrm{mg}$ of vitamin B2, $3 \mathrm{mg}$ of folic acid, $0.05 \mathrm{mg}$ of niacin, $900 \mathrm{IU}$ of vitamin D3, $2 \mathrm{mg}$ of vitamin $\mathrm{K} 3,2 \mathrm{mg}$ of vitamin B1, $2 \mathrm{mg}$ of vitamin $\mathrm{B} 6,0.05 \mathrm{mg}$ of biotin, $10 \mathrm{mg}$ of calcium pantothenate $/ \mathrm{kg}$ of pellets), and $0.1 \%$ methionine. The chemical analysis of the pellets showed that they contained 17.5\% CP (method 988.05) [16], 14.0\% crude fiber (method 989.03) [16], $2.7 \%$ crude fat, and $2200 \mathrm{kcal} / \mathrm{kg}$ of diet (method 920.39) [16]. Tap water was provided ad libitum and rats were acclimated for $2 \mathrm{wk}$ at $25^{\circ} \mathrm{C} \pm 1^{\circ} \mathrm{C}$ with a 12 -h dark and light cycle. After two weeks of acclimatization.

The animals were divided into five equal groups 6 animals in each group. Group 1 was used as a control. Group 2 diabetic rats; group 3, 4 and 5 were made diabetic and were treated with Hyphaene thebaica, daily at a dose of $(0.5 \mathrm{~g}$, $1 \mathrm{~g}$, and $2 \mathrm{~g} / \mathrm{kg} \mathrm{b} \cdot \mathrm{wt}$.) respectively, by intragastric tube. The tasted doses for Hyphaene thebaica were given every other day by stomach tube for 6 week by The rats were observed for signs of toxicity and mortality for the first $4 \mathrm{hr}$ and for 24 hr.

Blood samples were collected in dry test tubes and centrifuged at $860 \times \mathrm{g}$ for at $4^{\circ} \mathrm{C}$ for 20 minutes. The obtained plasma was kept at $-80^{\circ} \mathrm{C}$ for analysis [17].

Plasma samples were analyzed for glucose, total lipids, cholesterol, triglycerides (TG) and lactate dyhadreygenase Activity (LDH) according to the methods of [18] [19] [20] [21] [22], respectively. High-density lipoprote- 
in-cholesterol (HDL-c) was determined according to the methods of [23] [24]. Low-density lipoprotein-cholesterol (LDL-c) was determined by calculation (cholesterol-(TG/5+HDL).

The method of [25] was used to assay the activities of ALT and AST, whereas the ALP activity was determined according to the methods of [26].

Antioxidant Parameters like Catalase (CAT) enzyme and Malondialdehyde Activity were determined according to the methods of [27] [28].

\subsection{Histopathological Assay}

Specimens from pancreas were collected from all experimental groups and fixed in $10 \%$ neutral buffer formalin, dehydrated in ethyl alcohol and cleared in xylene. 4 - $5 \mu$ thick sections were prepared and stained with haematoxylin and Eo$\sin [29]$.

\subsection{Statistical Analysis}

The data were statistically analyzed according to [30]. Statistical significance of the difference in values of control and treated animals was calculated by $\mathrm{F}$ test with $1 \%$ and $5 \%$ significance level. Then, the data were statistically tested by using Duncan's Multiple Range Test [31].

\section{Results and Discussion}

\subsection{Plasma Glucose}

The data in Table 1 showed a significant increase in blood glucose level in diabetic rats of group 2 compared to that of normal control rats (group 1). While administration of doum extract caused significant decreases in blood glucose levels in rats of groups 3, 4 and 5 as compared to the diabetic rats. The increase in blood glucose may indicate disrupted carbohydrate metabolism due to enhanced breakdown of liver glycogen, possibly mediated by increase in adrenocorticotrophic and glucagon hormones and/or reduced insulin activity. These results are in agreement with those found by [32] who mentioned that giving doum extract orally led to significant decrease in blood glucose.

The data in Table 1 also, show that the levels of Insulin level in rats of groups 4 and 5 treated of doum extract decreased to be near that of the control group. Therefore, it seems that doum extract has an effective ability to keep the Insulin hormone at normal levels [11] reported that glucose levels were increased with a decrease in insulin levels, which was to due to the fact that type 2 diabetes mellitus was linked to reduced insulin release or insulin resistance, impaired glucose, lipid metabolisms, Also as activation of oxidative stress indices.

The hyperglycemia leads to an imbalance in the metabolism of carbohydrates and to inhibition of glucose utilization in animal body tissues such as muscles and fatty, etc. [33]. Therefore diabetes causes a significant increase in blood glucose and may thus raised hepatic glycogenolysis and gluconeogenesis as well as it reduces the transport of glucose from the blood to the tissues of the body. 
Table 1. Effect of doum fruit (Hyphaene thebaica) extract on plasma glucose $(\mathrm{mg} / 100 \mathrm{ml})$ and insulin (mIU/L).

\begin{tabular}{ccc}
\hline \multirow{2}{*}{ Group treatment } & \multicolumn{2}{c}{ Parameters } \\
\cline { 2 - 3 } & Glucose & Insulin \\
\hline Normal control & $121.50 \pm 13.54^{\mathrm{c}}$ & $0.69 \pm 0.03^{\mathrm{c}}$ \\
Diabetic Control & $368.00 \pm 30.51^{\mathrm{a}}$ & $1.04 \pm 0.14^{\mathrm{a}}$ \\
Diabetic + doum Extract 0.5 g/kg b·w & $217.33 \pm 40.10^{\mathrm{b}}$ & $1.03 \pm 0.24^{\mathrm{a}}$ \\
Diabetic + doum Extract 1 $\mathrm{g} / \mathrm{kg} \mathrm{wt}$ & $225.00 \pm 18.68^{\mathrm{b}}$ & $0.93 \pm 0.05^{\mathrm{ab}}$ \\
Diabetic + doum extract 2 $\mathrm{g} / \mathrm{kg} \mathrm{b} \cdot \mathrm{wt}$ & $161.33 \pm 16.50^{\mathrm{c}}$ & $0.77 \pm 0.06^{\mathrm{bc}}$ \\
\hline
\end{tabular}

Values are expressed as means \pm SE. Mean values within a row not sharing a common superscript letters (a, b) were significantly different, $p<0.05$.

The doum extract has an effective role in reducing blood glucose as it plays the role of insulin when glucose enters the cells and achieving optimal use of glucose [12].

\subsection{Blood Lipid Profile}

Effect of doum fruit extract on blood lipid profile is presented in Table 2. The results indicated that Levels of total lipid, triglyceride, Total cholesterol and LDL were higher in diabetic rats compared with normal control rats. While treatment with doum extract significantly $(P<0.05)$ decreased in the total lipids, triglyceride, total cholesterol and LDL of all treated groups as compared to the diabetic rats. On the other hand the value of HDL increased in all treated groups as compared with normal control and diabetic rats. Diabetes causes lipid metabolism due to insulin deficiency in the body resulting in damage to pancreatic cells. Insulin can activate are act as glucosidase inhibitors, reducing the lipoprotein lipase, the enzyme lipoprotein solver. These results are in agreement with other studies [32] [34].

Also observed that rats treated with doum extract showed a decrease in the level of fats and triglycerides and an increase in HDL-cholesterol at higher concentrations $250 \mathrm{mg} / \mathrm{kg}$ body weight, It is known that high levels of blood cholesterol and LDL are risk factors for cardiovascular disease, while HDL is involved in reverse cholesterol transport carring, cholesterol and cholesterol esters from the peripheral tissues and cells to the liver, where cholesterol is metabolized into bile acids, which reduces tissues cholesterol levels [35]. These results confirmed that the doum fruit is good source of flavonoids which are considered very important effective protect against cardiovascular diseases [36] in addition to enhancing the metabolic processes of carbohydrates due to their high content of bioactive compounds, such as polyphenols, flavonoids and carotenoids [37].

\subsection{Plasma Liver Enzymes}

Data presented in Table 3 showed the effect of the doum fruit (Hyphaene thebaica) extract on liver enzymes. The highest AlT, AST, ALP and LDH activity 
Table 2. Effect of doum fruit (Hyphaene thebaica) extract on plasma Lipid Profile ( $\mathrm{mg} / 100 \mathrm{ml})$.

\begin{tabular}{|c|c|c|c|c|c|}
\hline \multirow[b]{2}{*}{ Group treatment } & \multicolumn{5}{|c|}{ Parameters } \\
\hline & Triglyceride & Total Lipids & $\begin{array}{c}\text { Total } \\
\text { Cholesterol }\end{array}$ & $\begin{array}{c}\text { LDL } \\
\text { Cholesterol }\end{array}$ & $\begin{array}{c}\text { HDL } \\
\text { Cholesterol }\end{array}$ \\
\hline Normal control & $79.67 \pm 2.52^{\mathrm{cb}}$ & $467.67 \pm 49.80^{\mathrm{ab}}$ & $83.67 \pm 7.09^{b}$ & $82.97 \pm 7.12^{\mathrm{b}}$ & $15.23 \pm 1.35^{\mathrm{c}}$ \\
\hline Diabetic Control & $139.47 \pm 6.23^{\mathrm{a}}$ & $584.00 \pm 24.27^{\mathrm{a}}$ & $150.53 \pm 2.41^{\mathrm{a}}$ & $129.91 \pm 3.08^{\mathrm{a}}$ & $7.27 \pm 0.15^{\mathrm{d}}$ \\
\hline Diabetic + doum Extract $0.5 \mathrm{~g} / \mathrm{kg} \mathrm{b} \cdot \mathrm{w}$ & $99.87 \pm 21.92^{\mathrm{b}}$ & $347.33 \pm 72.76^{\mathrm{bc}}$ & $85.23 \pm 15.11^{b}$ & $80.63 \pm 19.49^{b}$ & $15.37 \pm 2.27^{c}$ \\
\hline Diabetic + doum Extract $1 \mathrm{~g} / \mathrm{kg}$ wt & $63.07 \pm 23.66^{c}$ & $257.67 \pm 64.49^{b}$ & $83.13 \pm 18.83^{c}$ & $94.15 \pm 17.86^{\mathrm{b}}$ & $23.63 \pm 4.59^{b}$ \\
\hline Diabetic + doum extract $2 \mathrm{~g} / \mathrm{kg} \mathrm{b} \cdot \mathrm{wt}$ & $48.87 \pm 22.72^{c}$ & $223.00 \pm 110.04^{\mathrm{c}}$ & $56.00 \pm 14.73^{c}$ & $76.43 \pm 19.21^{b}$ & $30.20 \pm 3.54^{\mathrm{a}}$ \\
\hline
\end{tabular}

Values are expressed as means $\pm \mathrm{SE}$. Mean values within a row not sharing a common superscript letters $(\mathrm{a}, \mathrm{b})$ were significantly different, $p<0.05$.

Table 3. Effect of doum fruit (Hyphaene thebaica) extract on plasma Liver Enzymes activities (IU/ml).

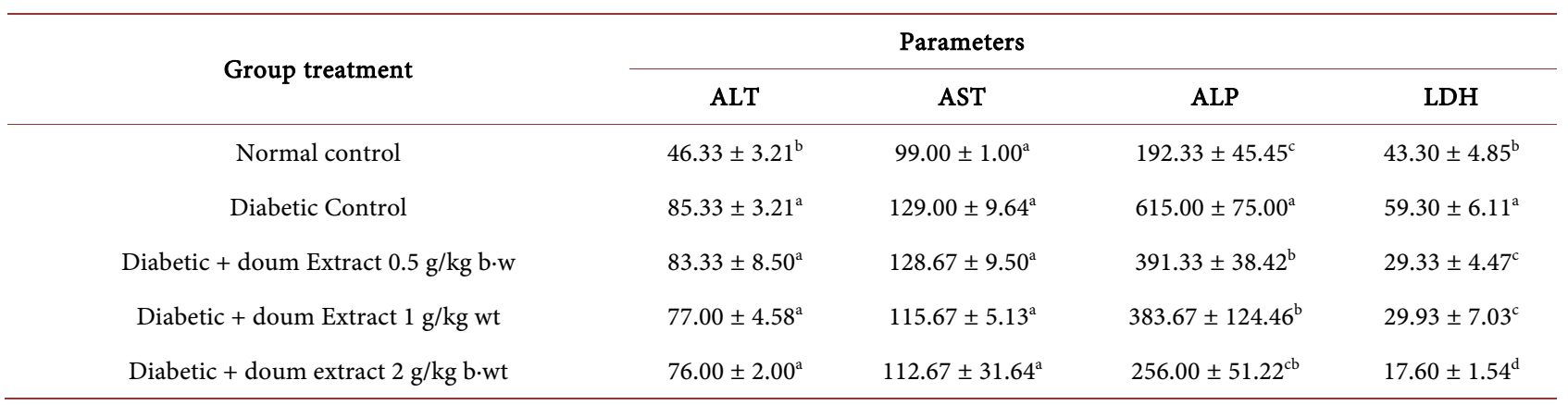

Values are expressed as means $\pm \mathrm{SE}$. Mean values within a row not sharing a common superscript letters $(\mathrm{a}, \mathrm{b})$ were significantly different, $p<0.05$.

was found in blood plasma of the diabetic rats group. Treatment with Hyphaene thebaica extract 1 and $2 \mathrm{~g} / \mathrm{kg} \mathrm{b} \cdot \mathrm{wt}$ significantly $(P<0.05)$ decreased the levels of ALP and LDH Meanwhile no significant $(P>0.05)$ difference was found in ALT and AST among all treated groups as compared to the diabetic rats. These results are in agreement with those of [38] [32].

The liver is the largest most complex organ in the body and plays major roles in a wide variety of biochemical functions of the body. Therefore, diseases of the liver will markedly affect the health [39].

Liver enzymes (ALT, AST and ALP) activities are important vital indicators for detecting liver toxicity, the increased levels of serum enzyme such as AST and ALT indicates that necrosis or damage to the liver cells [40].

The previous studies indicated that the doum fruit extract had no any harmful effect on the liver, but it improves the functions of enzymes (ALT, AST and ALP) activities. Research has focused on the nutritional value of it as it contains trace minerals and fatty acids, the most important of which is an essential important linoleic acid for the body and the doum extract is also rich in antioxidants as well as a large amount of water-soluble phenolic contents, Due to the high nutritional value, it is therefore used in treating different health problems and improving liver and kidney functions [15] [35].

$\mathrm{LDH}$ is the cytoplasm enzyme and is found in all cells of organs like organs, including the heart, the liver, the kidneys, the brain, red blood cells and the lung. 
It is used as an indication of inflammation or tissue damage. Also an increase in the serum causing cardiomyopathy, Studies have indicated that it increases significantly in diabetic rats [41] [42] [43].

\subsection{Antioxidant Enzymes Activity in Plasma}

Data recorded in Table 4 shows results of CAT activity in blood plasma and effect of the doum fruit extract on CAT activity. The lowest CAT activity was found in blood plasma of the diabetic group. Treatment with doum fruit extract led to significantly $(P<0.05)$ increased CAT activity compared with the diabetic rats group. While MDA activity groups were significantly $(P<0.05)$ decreased in plasma of rats treatment with doum fruit extract. This was attributed to the rich amount of flavonoids found in Hyphaene thebaica, which inhibits lipid oxidation by scavenging free radicals or by other mechanisms, such as singlet oxygen quenching, metal chelation, and lipoxygenase inhibition [15]. As well as the aqueous extract of Hyphaene thebaica which possesses an antioxidant activity due to its substantial amount of water-soluble phenolic content. These results are in agreement with other studies [34] [38].

As well doum contains high levels of phenol and flavonoids that possess antioxidant properties as it is known that phenolic compounds act as antioxidants due to their ability to give the hydrogen molecule and in addition to molecule inhibiting lipid oxidation by scavenging radicals, singlet oxygen quenching, metal chelation, and lipooxygenase inhibition [44].

\subsection{Histopathological Results}

The histological struture of the control rat pancreas shown that (Figure 1) shows normal histological structure of the island of langerhans cells, Also, It was found that lobules are composed largely of grape-like clusters of exocrine cells called acini, which secrete digestive enzymes embedded within the pancreatic exocrine tissue are islets of langerhans, the endocrine component of the pancreas.

(Figure 2) It shows that injection of alloxan effect in rats (group 2) caused shrinkage and vacuolizations of some cells in islets of langerhans of both alpha

Table 4. Effect of doum fruit (Hyphaene thebaica) extract on antioxidant Enzymes activity in Plasma.

\begin{tabular}{ccc}
\hline \multicolumn{2}{c}{ Parameters } & \\
\hline Group treatment & $\begin{array}{c}\text { Malondialdehyde } \\
(\mu \mathrm{mol} / \mathrm{ml})\end{array}$ & $\begin{array}{c}\text { Catalase } \\
(\mathrm{U} / \mathrm{ml})\end{array}$ \\
\hline Normal control & $14.03 \pm 0.59 \mathrm{~b}$ & $29.67 \pm 2.52 \mathrm{a}$ \\
Diabetic Control & $18.23 \pm 1.15 \mathrm{a}$ & $15.53 \pm 1.24 \mathrm{~b}$ \\
Diabetic + doum Extract $0.5 \mathrm{~g} / \mathrm{kg} \mathrm{b} \cdot \mathrm{w}$ & $11.23 \pm 3.52 \mathrm{cb}$ & $24.03 \pm 0.67 \mathrm{ab}$ \\
Diabetic + doum Extract $1 \mathrm{~g} / \mathrm{kg} \mathrm{wt}$ & $8.90 \pm 2.54 \mathrm{c}$ & $30.10 \pm 5.31 \mathrm{a}$ \\
Diabetic + doum extract $2 \mathrm{~g} / \mathrm{kg} \mathrm{b} \cdot \mathrm{wt}$ & $4.70 \pm 0.46 \mathrm{~d}$ & $33.80 \pm 9.46 \mathrm{a}$ \\
\hline
\end{tabular}

Values are expressed as means \pm SE. Mean values within a row not sharing a common superscript letters (a, b) were significantly different, $p<0.05$. 


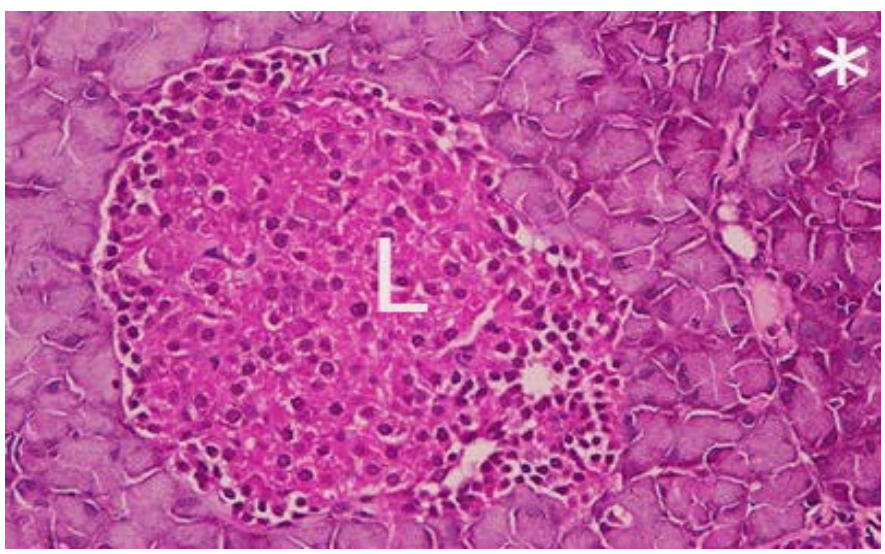

Figure 1. Photomicrograph section in pancreas cell of normal rat (control) showing the normal histological structure langerhans (L) and acinar cells $\left(^{*}\right)$, (H \& E stain $\left.400 \times\right)$.

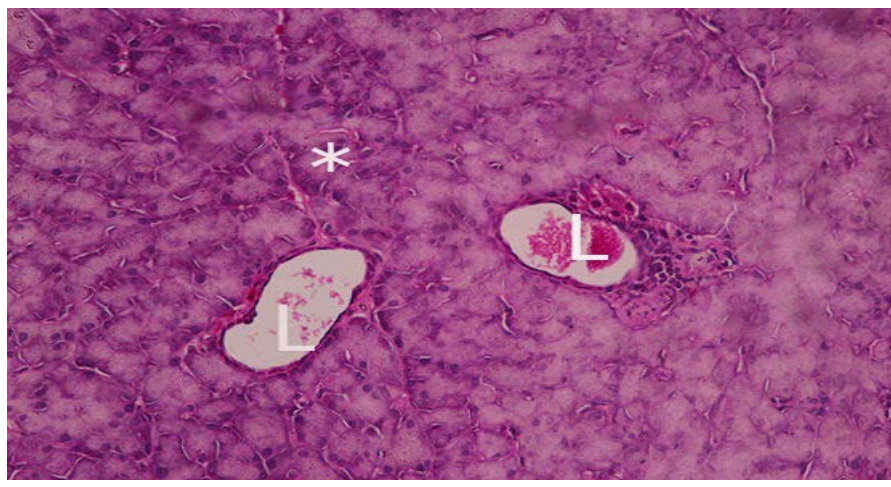

Figure 2. Photomicrograph of pancreas of diabetic (control) rats (Alloxan-Diabetic) showing shrinkage in islets of Langerhans (L) and sign of necrotic islet cells (L), (H \& E stain 400x).

and beta as well as found necrotic in beta Langerhans This may be due to the fact that diabetes affects the lipid metabolism due to insulin deficiency in the body, which leads to necrosis and damage to beta langerhans cells [34].

Treatment of alloxan diabetic rat (group 3) with doum fruit extract $(0.5 \mathrm{~g} / \mathrm{kg}$ $\mathrm{b} \cdot \mathrm{w})$ showed the size of islets of langerhans cells was moderate and slight congestion between acinar cells as observed (Figure 3). However treatment with doum fruit extract ( 1 and $2 \mathrm{~g} / \mathrm{kg} \mathrm{b} \cdot \mathrm{w}$ ) caused marked improvement in the islets form of Langerhans cells and becoming to normal acinar cells and normal histological structure of pancreatic tissue as shown (Figure 4 and Figure 5). The hypoglycemic effect on blood glucose level could be through increased serum insulin levels provided by repair/regeneration of the endocrine pancreas [45].

\section{Conclusion}

From the present results, it can be concluded that hyphaene thebaica extract treatments improved blood glucose levels, liver enzyme serum AST, ALT and ALP) lipid profile (serum triglycerides, total lipids, cholesterol) antioxidant 


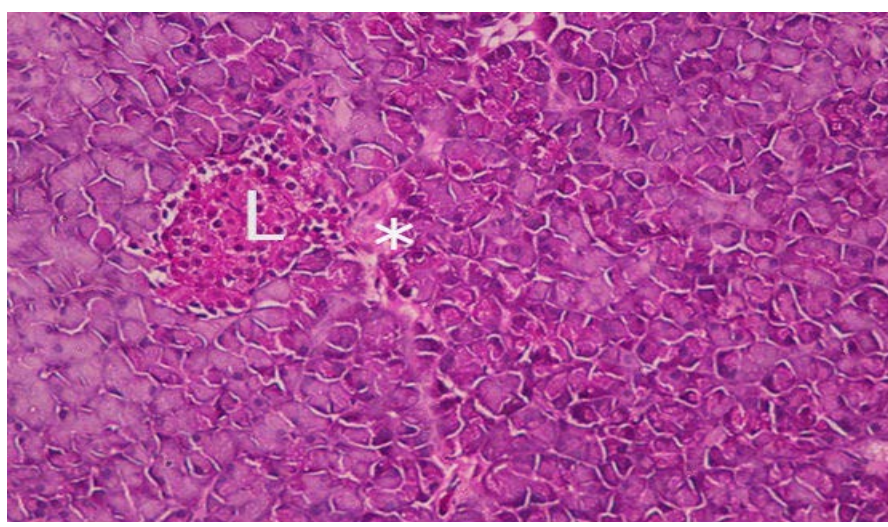

Figure 3. Photomicrograph of pancreas of diabetic rats treated with hyphaene thebaica extract $0.5 \mathrm{~g} / \mathrm{kg}$ body weight showing moderate of langerhans (L) and and slight congestion between acinar cells $\left.{ }^{*}\right),(\mathrm{H} \& \mathrm{E}$ stain $400 \times$ ).

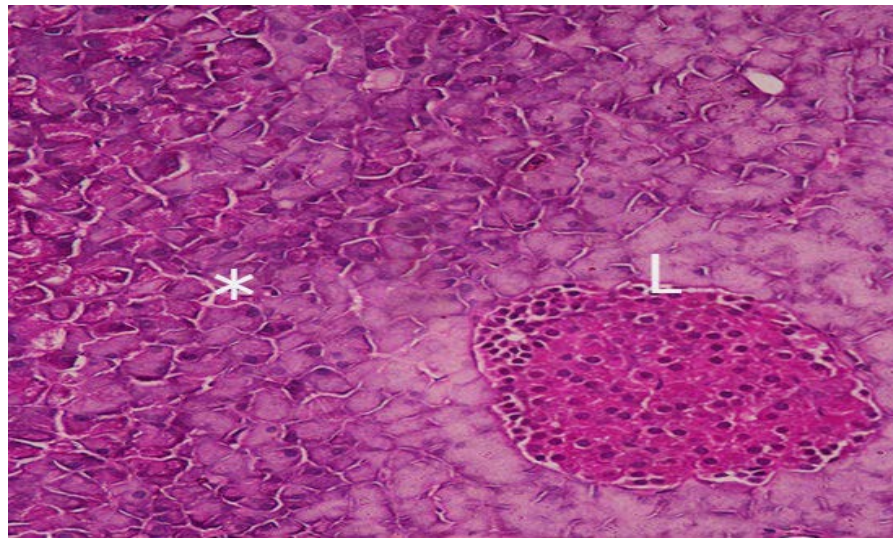

Figure 4. Photomicrograph of pancreas of diabetic rats treated with hyphaene thebaica extract $1 \mathrm{~g} / \mathrm{kg}$ b·wt body weight showing relatively normal acinar cells $\left({ }^{*}\right)$, normal islet's of langerhans $(\mathrm{L}),(\mathrm{H} \&$ E stain $400 \times s)$.

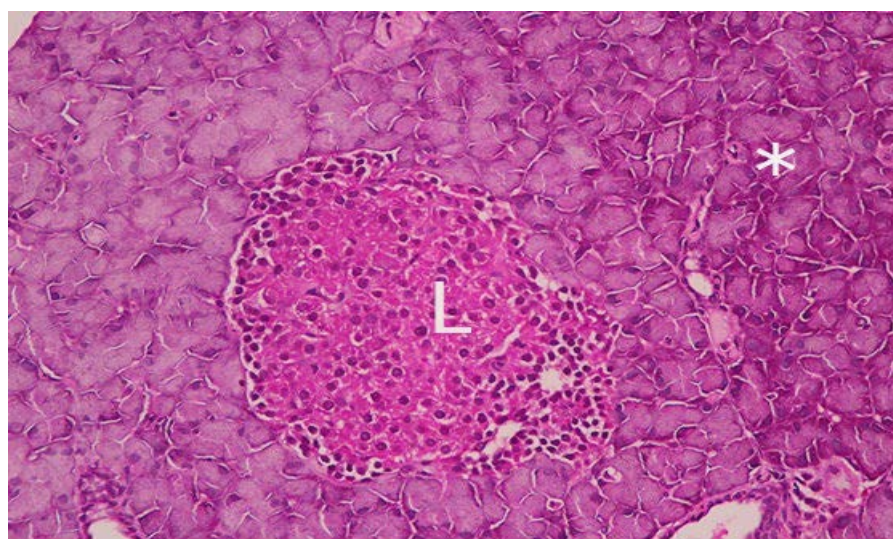

Figure 5. Photomicrograph of pancreas of diabetic rats treated with hyphaene thebaica extract $2 \mathrm{~g} / \mathrm{kg}$ b.wt body weight showing normal acinar cells $\left(^{*}\right)$, and normal islet's of langerhans (L), (H \& E stain $400 \times$ s). 
status which includes catalase and malondialdehyde. This confirms the health benefits of doum extract which might be due to the presence of flavonoids and phenolic compound.

\section{Acknowledgements}

The author is pleased to extend sincere, deep thanks and gratitude Prof. Isis Azer Nawar, Department of Home Economics, Faculty of Agriculture, Alexandria University, Egypt, for her revision in this manuscript. Also, I would like to thank Dr. Maha Ibrahim Kamal Ali, Department of Special Food and Nutrition, Food Technology Research Institute, Agricultural Research Center, Giza, Egypt, for helping in statistical analysis.

\section{Conflicts of Interest}

The authors declare no conflicts of interest regarding the publication of this paper.

\section{References}

[1] Mohamed, A.A., Khalil, A.A. and El-Beltagi, H.E.S. (2010) Antioxidant and Antimicrobial Properties of Kaff Maryam (Anastatica hierochuntica) and Doum Palm (Hyphaene thebaica). Grasas Y Aceites, 61, 67-75. https://doi.org/10.3989/gya.064509

[2] Afify, A.M.R., El-Beltagi, H.S., Hammama, A.A.E., Sidky, M.M. and Mostafa, O.F.A. (2011) Distribution of Trans-Anethole and Estragole in Fennel (Foeniculum vulgare Mill) of Callus Induced from Different Seedling Parts and Fruits. Notulae Scientia Biologicae, 3, 79-86. https://doi.org/10.15835/nsb315422

[3] Gutch, M., Razi, S.M., Kumar, S. and Gupta, K.K. (2014) Diabetes Mellitus: Trends in Northern India. The Indian Journal of Endocrinology and Metabolism, 18, 731-734.

[4] Tramonti, G. and Kanwar, Y.S. (2013) Review and Discussion of Tubular Biomarkers in the Diagnosis and Management of Diabetic Nephropathy. Endocrine, 43, 494-503. https://doi.org/10.1007/s12020-012-9820-y

[5] Nyenwe, E.A., Jerkins, T.W., Umpierrez, G.E. and Kitabchi, A.E. (2011) Management of Type 2 Diabetes: Evolving Strategies for the Treatment of Patients with Type 2 Diabetes. Metabolism, 60, 1-23. https://doi.org/10.1016/j.metabol.2010.09.010

[6] Shallan, M.A., Ahmed, A.I., Thabt, H. and Abdel-Rahim, E.A. (1998) Synergetic Effect of Chromium and Fenugreek Seeds as the Hypoglycemic, Hypolipidemic and Hypocholesterolemic Influences in Diabetic Animals. The Journal of Agricultural Science, Mansoura University, 23, 5713-5728.

[7] Orwa, C., Mutua, A., Kindt, R., Jamnadass, R. and Simons, A. (2009) Agroforestree Database: A Tree Reference and Selection Guide. Version 4.

[8] Eldahshan, O., Ayoub, N., Singab, A. and Al-Azizi, M. (2008) Potential Superoxide Anion Radical Scavenging Activity of Doum Palm (Hyphaen thebaica L.) Leaves Extract. Records of Natural Products, 2, 83-93. http://www.diabetesatlas.org

[9] Eldahshan, O., Ayoub, N., Singab, A. and Al-Azizi, M. (2009) Potential Antioxidant Phenolic Metabolites from Doum Palm Leaves. African Journal of Pharmacy and 
Pharmacology, 3, 158-164.

[10] Shehu, B., Gidado, A. and Buratai, L. (2014) Hypoglycaemic, Hypolipidaemic and Possible Toxicity of the Methanolic Fruit Pulp Extract of Hyphane thebaica (L) Mart in Alloxan-Induced Diabetic Rats. Journal of Medical and Applied Biosciences, 6, 1-10.

[11] Abdel-moniem, M., Mustafa, H.N., Megahed, H.A., Agaibyi, M.H., Hegazy, G.A. and El-Dabaa, M.A. (2015) The Ameliorative Potential of Hyphaene thebaica on Streptozotocin-Induced Diabetic Nephropathy. Folia Morphologica, 74, 447-457. https://doi.org/10.5603/FM.2015.0106

[12] Abdel-Rahim, E.A., El-Beltagi, H.S. and Fayed, S.A. (2011) Comparative Studies on the Influences of Juniperus phoenicea and Hyphaene thebaica as Hypoglycemic Factors in Diabetic Rats. Advances in Food Sciences, 33, 128-132.

[13] Mansour, H.A., Newairy, A.S., Yousef, M.I. and Sheweita, A. (2002) Biochemical Study on the Effects of Some Egyptian Herbs in Alloxan-Induced Diabetic Rats. Toxicology, 170, 221-228. https://doi.org/10.1016/S0300-483X(01)00555-8

[14] Sheweita, S.A., Newairy, A.A., Mansour, H.A. and Yousef, I. (2002) Effect of Some Hypoglycemic Herbs I and II Drug-Metabolizing Enzymes in Alloxan-Induced Diabetic Rats. Toxicology, 174, 131-139. https://doi.org/10.1016/S0300-483X(02)00048-3

[15] Hsu, B., Coupar, I.M. and Ng, K. (2006) Antioxidant Activity of Hot Water Extract from the Fruit of the Doum Palm, Hyphaene thebaica. Food Chemistry, 98, 317-328. https://doi.org/10.1016/j.foodchem.2005.05.077

[16] AOAC (1990) Official Methods of Analysis of the Association of Official Analytical Agricultural Chemists. 13th Edition, AOAC, Washington DC.

[17] El-Demerdash, F.M., Yousef, M.L. and Abou El-Naga, N.L. (2005) Biochemical Study on the Hypoglycemic Effects of Onion and Garlic in Alloxan-Induced Diabetic Rats. Food and Chemical Toxicology, 43, 57-63. https://doi.org/10.1016/j.fct.2004.08.012

[18] Zollner, N. and Kirsch, K. (1962) Ueber die quantitative bestimnung von lipoiden (mikromethod) mittels der vielen naturlichel lipoiden (allen bekannten plasmalipoiden) gemeisamen sulphophospho-vanillin reaction. Zeitschrift für die gesamte experimentelle Medizin, 135, 545-561. https://doi.org/10.1007/BF02045455

[19] Trinder, P. (1969) Determination of Glucose in Blood Using Glucose Oxidase with an Alternative Oxygen Acceptor. Annals of Clinical Biochemistry, 6, 24-27. https://doi.org/10.1177/000456326900600108

[20] Bucolo, G. and David, H. (1973) Quantitative Determination of Serum Triglycerides by Use of Enzymes. Clinical Chemistry, 19, 476-482. https://doi.org/10.1093/clinchem/19.5.476

[21] Fossati, P. and Prencipe, L. (1982) Serum Triglycerides Determined Calorimetrically with an Enzyme That Produces Hydrogen Peroxide. Clinical Chemistry, 28, 2077-2080. https://doi.org/10.1093/clinchem/28.10.2077

[22] Czok, R., Lamprecht, W. and Latzko, E. (1962) Methoden der enzymatischen Analyse. Verlag Chemie, Weinheim, 253-259.

[23] Grove, T.H. (1979) The Effect of Reagent pH on Determination of High-Density Lipoprotein Cholesterol by Precipitation of with Sodium Phosphotungstate-Magnesium. Clinical Chemistry, 25, 560-564. https://doi.org/10.1093/clinchem/25.4.560

[24] Burstein, M., Scholnick, H.R. and Morfin, R. (1980) Rapid Method for Isolation of Lipoproteins from Human Serum by Precipitation with Polyanions. Scandinavian 
Journal of Clinical and Laboratory Investigation, 40, 583-595.

[25] Reitman, S. and Frankel, S. (1957) A Colorimetric Method for the Determination of Serum Glutamic Oxaloacetic and Glutamic Pyruvic Transaminases. American Journal of Clinical Pathology, 26, 56-63. https://doi.org/10.1093/ajcp/28.1.56

[26] Belfield, A. and Goldberg, D.M. (1971) Revised Assay for Serum Phenyl Phosphatase Activity Using 4-Amino-Antipyrine. Enzyme, 12, 561-573. https://doi.org/10.1159/000459586

[27] Aebi, H. (1984) Catalase in Vitro. In: Methods in Enzymology, Vol. 105, Academic Press, Cambridge, 121-126. https://doi.org/10.1016/S0076-6879(84)05016-3

[28] Satoh, K.E.I. (1978) Serum Lipid Peroxide in Cerebrovascular Disorders Determined by a New Colorimetric Method. Clinica Chimica Acta, 90, 37-43. https://doi.org/10.1016/0009-8981(78)90081-5

[29] Bancroft, G.D., Stevens, A. and Turner, D.R. (1996) Theory and Practice of Histopathological Technique. 4th Edition, Churchill Livingston, New York, London, San Francisco and Tokyo.

[30] Steel, R.G.D. and Torrie, J.H. (1981) Principles and Procedures of Statistics. A Biometrical Approach. 2nd Edition, McGraw-Hill Book Company, New York.

[31] SAS (2004) SAS Institute Inc. SAS./ETS9.1 User SAS Institute Inc Users Guide. Cary.

[32] Bayad, A.E. (2016) Influences of Doum Fruit Hyphaene thebaica Extract on the Reproductive Parameters, Blood Picture, Lipid Profile and Hepato-Renal Functions in Rats. MRJMMS, 4, 384-391.

[33] Hansen, M. (1998) Pathophysiology, Foundation of Disease and Clinical Intervention. WB Saunders Company, Philadelphia, 851-852.

[34] Abdulazeez, M.A., Bashir, A., Adoyi, B.S., Mustapha, A.Z., Kurfi, B., Usman, A.Y. and Bala, R.K. (2019) Antioxidant, Hypolipidemic and Angiotensin Converting Enzyme Inhibitory Effects of Flavonoid-Rich Fraction of Hyphaene thebaica (Doum Palm) Fruits on Fat-Fed Obese Wistar Rats. Asian Journal of Research in Biochemistry, 5, 1-11. https://doi.org/10.9734/ajrb/2019/v5i330091

[35] Kamis, A.B., Modu, S. and Markus, P.Y. (2003) Some Biochemical Effects of Various Doses of Ethanolic Pulp Extract of Hyphaene thebaica. Nigerian Journal of EXperimental and Applied Biology, 1, 33-36.

[36] Kim, H., Jeong, D., Jung, H., Yokozawa, T. and Choi, J. (2008) Hypolipidemic Effects of Sophora flavescens and Its Constituents in Poloxamer 407-Induced Hyperlipidemic and Cholesterol-Fed Rats. Biological and Pharmaceutical Bulletin, 31, 73-78. https://doi.org/10.1248/bpb.31.73

[37] Singh, J.P., Kaur, A., Shevkani, K. and Singh, N. (2016) Composition, Bioactive Compounds and Antioxidant Activity of Common Indian Fruits and Vegetables. Journal of Food Science and Technology, 53, 4056-4066. https://doi.org/10.1007/s13197-016-2412-8

[38] Al-Masri, S.A. and Riyadh, S.A. (2012) Effect of Doum and Methionine Combination on Hepatotoxicity in Rats. Australian Journal of Basic and Applied Sciences, 6 , 392-397.

[39] Finkelstein, J.D. (1990) Methionine Metabolism in Mammals. Journal of Nutritional Biochemistry, 1, 228-237. https://doi.org/10.1016/0955-2863(90)90070-2

[40] Hasan, F. (2011) Anti-Hepatotoxic Effect of the Methanolic Anstatica Hierochuntica Extract in CCl4-Treated Rats. Engineering and Technology Journal, 29, 413-423.

[41] Kato, G.J., McGowan, V., Machado, R.F., et al. (2006) Lactate Dehydrogenase as a 
Biomarker of Hemolysis-Associated Nitric Oxide Resistance, Scavenger Receptor Class B Type I Priapism, Leg Ulceration, Pulmonary Hypertension and Death in Patients with Sickle Cell Disease. Blood, 107, 2279-2285.

https://doi.org/10.1182/blood-2005-06-2373

[42] Giribabu, N., Roslan, J., Rekha, S.S. and Salleh, N. (2016) Methanolic Seed Extract of Vitis vinifera Ameliorates Oxidative Stress, Inflammation and ATPase Pak Dysfunction in Infarcted and Non-Infarcted Heart of 81 Streptozotocin-Nicotinamide Induced Male Diabetic Rats. International Journal of Cardiology, 222, 850-865. https://doi.org/10.1016/j.ijcard.2016.07.250

[43] Suanarunsawat, T., Anantasomboon, G. and Piewbang, C. (2016) Anti-Diabetic and Anti-Oxidative Activity of Fixed Oil Extracted from Ocimum sanctum L. Leaves in Diabetic Rats. Experimental and Therapeutic Medicine, 11, 832-840. https://doi.org/10.3892/etm.2016.2991

[44] Huyut, Z., Beydemir, Ş. and Gülçin, İ. (2017) Antioxidant and Antiradical Properties of Selected Flavonoids and Phenolic Compounds. Biochemistry Research International, 2017, Article ID: 7616791. https://doi.org/10.1155/2017/7616791

[45] Rahmy, T.R. and El-Ridi, M.R. (2002) Action of Anas-Tatica Hierochuntica Plant Extract on Islets of Langerhans in Normal and Diabetic Rats. Egyptian Journal of Biology, 4, 87-94. 